\title{
An Examination of the Impacts of Fiscal Decentralization on Economic Growth
}

\author{
Francis Amagoh \\ Department of Public Administration, KIMEP University, Almaty, Kazakhstan \\ E-mail: famagoh@yahoo.com, famagoh@Kimep.kz
}

Aloysius Ajab Amin

Department of Economics, KIMEP University, Almaty, Kazakhstan

E-mail: amin@kimep.kz

Received: September 17, 2012

Accepted: October 4, 2012

Online Published: October 26, 2012

doi:10.5430/ijba.v3n6p72

URL: http://dx.doi.org/10.5430/ijba.v3n6p72

\begin{abstract}
Fiscal decentralization is said to offer a number of benefits for public sector governance, including growth, accountability and responsiveness of government officials to local demands and needs. However, there has been debate about the effects of fiscal decentralization on macroeconomic performance and growth. In this paper, we examine both sides of the arguments and posit that while there are many benefits to be gained from fiscal decentralization, its impacts on economic growth is constrained by a number of factors that are based on the contexts of the societies/economies involved. Hence the positive impact of fiscal decentralization on growth depends on the context and the society/economy.
\end{abstract}

Keywords: Fiscal decentralization, Economic growth, Budget, Accountability, Governance, Multi-tier government

\section{Introduction}

Interest in fiscal decentralization has been rising in recent years because of the potential benefits to be derived from its implementation. Fiscal decentralization occurs when sub-national governmental units are given autonomy over the provision and financing of public goods and services (Bjedov and Madies, 2010:12-32). It may happen either by a proper delegation of authorities to the sub-national units (which may act on behalf of the central government in implementing revenue and expenditure policies), or by devolution, whereby local governments not only implement the programs of the central government but have considerable authority to decide the financing mechanisms (Golem, 2010:53-69). The fiscal decentralization approach treats local government as a subordinate tier in a multi-tiered system and usually outlines principles for defining the roles and responsibilities of orders of government (Shah and Shah, 2007:72-80). It is therefore seen as a means to produce more efficient and effective governance, macroeconomic stability and adequate growth at all levels (Miller and Russek, 1997:213-237). Since there usually are widespread divergence between sub-national responsibilities for expenditures and revenues, decentralized countries often have a large degree of vertical fiscal imbalance, which may be bridged through transfers from the central government to sub-national governments.

International organizations, such as, the World Bank, the African Development Bank, the Asian Development Bank, the Organization for Economic Cooperation and Development, and the Inter-American Development Bank have not only been urging member countries to embrace fiscal decentralization; but they have also been supporting and encouraging countries to carry out decentralization of their economies as part of a broader strategy for enhancing public sector efficiency. These organizations believe that fiscal decentralization strengthens participatory decision-making at local government levels, which would lead to accelerated economic growth and development (Grewal, 2010:1-12).

Despite the widening appeal of fiscal decentralization, it remains controversial regarding its benefits on promoting economic growth. A number of studies question the validity of the positive impact of fiscal decentralization on economic growth, and suggest that fiscal decentralization may even be detrimental to the overall macroeconomic 
performance of a country. The purpose of this paper is to examine both sides of the argument. While fiscal decentralization offers a number of benefits essential for public sector governance, its impact on economic growth remains inconclusive. We find that the positive impact of decentralization on growth depends on a number of factors, including institutional factors that are based on the contexts of the societies/economy involved. The rest of this paper is organized as follow. In Section 2 we discuss the benefits of fiscal decentralization. Section 3 discusses both sides of the argument on fiscal decentralization and economic growth. In Section 4, we present various studies on the relationship between fiscal decentralization and economic growth. Section 5 is the discussion, while Section 6 is the conclusion.

\section{Benefits of Fiscal Decentralization}

The fiscal decentralization literature indentifies major gains to be derived by granting more taxing and spending powers to sub-regional governments. These gains revolve around two basic issues: accountability and responsiveness; and sub-national autonomy.

\subsection{Accountability and Responsiveness}

Proponents of fiscal decentralization argue that if sub-national governments are responsible for administering their own tax revenues, they will be held accountable by local populations (Freinkman, 2010:117-168). The decentralized form of government, therefore, brings about welfare-enhancing results and makes local officials more accountable and responsible. With fiscal decentralization, sub-national governments are closer and more responsive to the needs and preferences of local residents, thereby allowing a closer match between the preferences of the population and the mix of public goods and services delivered by government (Golem, 2010). It is argued that local population can exert pressure on local officials regarding the quality of services provided (Alexeev and Habodaszova, 2012:74-99). This increases the responsiveness of local governments to the demands of local residents by providing a range of outputs of public goods and services that correspond closely to the differing tastes of groups of residents (Oates, 1977). It relives the central government from many tasks, allowing it to concentrate better on efficient production of those public goods and services for which it still bears responsibility (goods and services with large spillovers among communities and/or substantial economies of scale in production) (Grewal, 2010:1-12). This is in contrast to centralization which, while it provides the benefits of policy coordination (especially where there are spillovers across jurisdictions), has costs in terms of diminished accountability (i.e. reduced probability that the welfare of a given locality can determine the re-election of the central government).

\subsection{Sub-national Autonomy}

A measure of autonomy for sub-national governments on revenues and expenditures is essential for realizing the efficiency gains of decentralized government, and supporting macroeconomic stability. Sub-national autonomy allows regional governments to have sufficient political autonomy and be subject to effective political competition. It lessens concentration of political power and weakens the influence of vested interests on public policy, thus promoting democracy, development and long-term economic growth (Thiessen, 2003:237-274). The measure of fiscal decentralization that best reflects incentive effects at the sub-national level is revenue autonomy, or the share of local government expenditure financed by own-source revenue (Freinkman, 2010:117-168). This means that sub-national governments must have the authority to own-finance locally provided services. More complete revenue autonomy requires at a minimum, the authority to set tax rates, and an assignment of at least one significant tax source (Vigneault, 2010:48-79). This allows local governments to invest in policies that with time increase their revenue base and thus the value of their office. Without fiscal decentralization, local officials lack incentives to pursue pro-growth policies if all the benefits of growth and development accrue to higher-tier governments. Similarly, if officials of the central government merely administer central funds, they may lack incentives to put forth extra effort in improving quality of public services at local levels, since they may not derive economic or political benefits from the results of their actions.

On the expenditure side, sub-national budget autonomy provides local officials the flexibility to decide expenditure priorities, and the choice of both the output mix and techniques of production. There are two main issues to be concerned with when it comes to sub-national autonomy; namely, regional inequality and lack of fiscal discipline. With sub-national autonomy, there is a potential for regional inequality since resources among the various regions of the country are not uniformly distributed. Therefore, achieving meaningful and sustainable autonomy at the sub-national level and avoiding an inequitable geographical reallocation of resources require a framework that ensures sub-national governments provide relatively uniform service levels at reasonable levels of tax effort (Kolluri and Panik, 2000:1059-1068). 
With regards to the issue of fiscal discipline, it is possible that sub-national governments may not use prudence in their expenditures. Thus, while autonomy should be well-defined, it must also be circumscribed with respect to access to borrowing by sub-national governments in order to support hard budget constraints (whereby sub-nationals do not expect financial relief from the central government whenever they are in financial distress), and reduce moral hazard. Excessive sub-national borrowing in the absence of market discipline, and a sound, effective and strictly enforced regulatory framework can undermine achieving fiscal targets for the general government, and pose a risk to macro-fiscal stability (Bardhan, 2002:185-205). Thus, the framework for sub-national borrowing requires an appropriate balance of market discipline, rules-based controls, and administrative oversight and supervision (Grewal, 2010:1-12).

\section{Fiscal Decentralization and Economic Growth}

\subsection{The Pro-growth Arguments}

One argument supporting the positive effects of fiscal decentralization on economic growth is the "diversification hypothesis" which maintains that uniform levels of public goods and services across jurisdictions will generally be inefficient (Oates, 1977). The model assumes that there is a uniform level of public service being offered in each community. Thus, if in a model of only two communities and each has a different demand for a public service being offered, with immobile individuals, no economies of scale in the production of the public service and no spillover effects from one community to the other, then such service provision is inefficient (Thiessen, 2003:237-274). This is because the marginal benefits of the public service differ due to the different demand schedules in each community. With mobility of people introduced into the model, the incentives for individuals to move to the community that is perceived as supplying the best combination of public service and local tax rate is increased. Therefore, resources can be saved without detriment to anyone involved by diversifying government production to meet local demands, thereby creating greater "consumer efficiency". By so doing, individuals contribute to efficient resource allocation. Even with identical individual preferences and relative immobility, fiscal decentralization may still offer efficiency advantages if decisions by sub-national governments better reflect the priorities of taxpayers. Since centrally-determined policies do not consider regional and local conditions in the provision of public goods and services as well as locally-determined policies (for instance, regarding infrastructure and education), economic development and growth might be promoted if local authorities have input into such policy decisions (Oates, 1977, 1993; Thiessen, 2003:237-274).

Similarly, Vazquez and McNab (2003:1597-1619) suggest that fiscal decentralization promotes economic growth through the "productivity enhancement" hypothesis. The productivity enhancement hypothesis states that by transferring accountability to sub-national governments, local governments are given the incentive, not only to consider local residents' preferences, but also to search actively for innovations in the production and supply of public goods and services. Production costs and prices of public goods and services could thus be lower and their quality better in the long-run because of the innovative practices (i.e. greater "producer efficiency") (Vazquez and McNab, 2003:1593-1619).

Another argument supporting the claim that fiscal decentralization promotes economic growth was proposed by Brennan and Buchanan (1980) in the "Leviathan restraint hypothesis". The hypothesis states that governments behave as revenue-maximizers to the detriment of taxpayers. Government is a monolithic Leviathan, which seeks to maximize revenues and increase its size, through excessive taxation, debt or money creation. Thus, greater centralization (i.e. "monopolization" of government), combined with a weak intergovernmental competition, lead to a larger government size in the economy. The Leviathan effect can be restrained through constitutional constraints (such as balanced-budget provision) which limits government's spending powers, or through fiscal decentralization. With fiscal decentralization (assuming that firms and citizens are mobile across jurisdictions), any attempt by one sub-national government to unduly raise taxes will result in a migration of its firms and citizens to an alternative sub-national unit with lower tax rates. Due to this competitive pressure, sub-national governments will aim to reduce taxes and make more judicious use of their revenues.

The thrust of the Leviathan hypothesis, therefore, is that fiscal decentralization brings about competition among different levels of government, and prevents revenue maximization by governments. This allows competing governments to focus on objectives other than revenue maximization (such as lowering taxes, and efficient production of public goods and services) under certain revenue constraints. It thus restrains the size of governments' budgets and prevents an oversupply of public goods and services. The result would be a positive impact on per capita growth due to more efficient use of resources (Thiessen, 2003:237-274; Golem, 2010:53-69). It should be noted that in the Leviathan hypothesis, revenue generation is assumed to be independent of the demand for publicly provided 
goods and services (Golem, 2010:53-69). Furthermore, decentralized provision of public services enhances the quality of public services since sub-national governments have superior knowledge of local preferences and needs, and thus are able to target public spending better (Freinkman, 2010:117-168; Oates, 2005:349-373). In a highly decentralized structure of governance, voters in adjacent jurisdictions can relatively easily compare their relative positions and penalize their sub-national government for excessive and wasteful spending (Alexeev and Habodaszova, 2012:74-99). Satisfaction of residents' needs prevents business relocation and tax base migration, reduces fiscal stress, and ultimately promotes economic growth (Feld et al., 2010:27-48).

\subsection{The Anti-growth Arguments}

While there are some gains to be derived from fiscal decentralization, there are also concerns that if not properly designed, decentralization programs may pose problems to the general economy. Some of these problems are identified as soft budget, developing countries, capture, and social fragmentation.

\subsubsection{Soft Budget}

A soft budget constraint arises when sub-national governments continually expect to be bailed out by the central government in cases of fiscal distress (Kornai, 1979:801-819, 1980). On the other hand, as already mentioned, a hard budget constraint implies that sub-national governments cannot expect additional subsidies or transfers from the central government when in financial difficulty. This reduces opportunistic behavior on the part of sub-national governments and provides incentives for fiscal discipline. The issue of soft budget constraint is important because of incentive problems that arise when regional governments expect part or all of their spending and/or borrowing costs to be covered by the central government in the form of additional transfers (Vigneault, 2010:48-79). Typically, this type of incentive problem arises because regional governments do not take into account the welfare of national taxpayers when making their spending and/or borrowing decisions, thereby resulting in negative externality at the national level. With too much spending or borrowing undertaken by regional governments relative to the efficient level, soft budgets can lead to macroeconomic instability and inefficiency (Feld et al., 2010:27-48). Fiscal decentralization may thus aggravate fiscal imbalances, thereby, endangering overall macroeconomic stability, unless sub-national governments are committed to fiscal discipline, and the decentralization package includes incentives for prudence in debt and expenditure management (Dabla-Norris, 2006:100-131).

\subsubsection{Spillovers}

A major goal of the central government is to ensure macroeconomic stability and growth. For efficiency and equity, the macroeconomic stabilization function of government should largely be performed by the central government because the mobility of resources across regional boundaries makes it unlikely that a stabilization policy can be pursued by a lower level of administration (Desai et al., 2005:814-834). The argument for fiscal decentralization is thereby weakened if the costs of regional provision of services are higher due to the smaller scale of regional administration operations; and if there are substantial spillovers from regional administration expenditures (Neck and Getzner, 2007:49-65). Any attempt by regional governments to provide such goods and services would lead to inefficient allocation of resources.

Furthermore, with spillovers, decentralization could lead to under-provision of local public goods, as local decision makers do not take into account benefits going to other districts (Barankay and Lockwood, 2007:1197-1218). The issue of spillovers is especially relevant to investment in certain areas, like highway transport, communication, and controlling pollution or epidemics. Spillover is however, less relevant when the public goods are more local, such as in local roads, minor irrigation, village health clinics, sanitation, and identification of beneficiaries of public transfer programs (Brothaler and Getzner, 2010:169-206). When spillover is unavoidable, centralization is necessary to ensure macroeconomic stabilization and efficiency. With spillovers and no heterogeneity, it is more efficient for a central government to provide a common level of public goods and services for all localities. The central government's expenditures in these areas generally generate much positive externalities and at the same time, the central government would aim to reduce or eliminate potential negative externalities that may occur.

\subsubsection{Developing Countries}

Much of the fiscal decentralization literature discusses the economic efficiency of intergovernmental competition, which often starts with Tiebout's (1956) model of market efficiency. Tiebout's model of market efficiency states that when different local governments offer different public tax-expenditure bundles, mobile individuals tend to allocate themselves according to their preferences. However, according to Bardhan (2002:185-205), the assumptions that underlie this efficiency gains argument for fiscal decentralization may not really apply to low-income and developing countries for the following reasons. 
First, while the literature on fiscal federalism focuses on allocation of funds, and assumes that allocated funds automatically reach their intended beneficiaries, it ignores the mechanisms and devices needed to check bureaucratic corruption common in some developing countries. Corruption therefore means that allocated funds do not necessarily reach their intended beneficiaries, or be used for their intended purposes. Second, when a major goal of decentralization in developing countries is to effectively reach out to the poor (or to diffuse unrest among disadvantaged minority groups), targeting success in poverty reduction programs is a more important performance criterion than the efficiency of inter-regional resource allocation brought about by fiscal decentralization (Bardhan, 2002:185-205; Vasquez and McNab, 2003:1597-1619). Third, with regards to the issue of checks and balances and how to restrain the central government's power, in many situations in developing countries, the poor and the minorities who may be oppressed by the local power groups often look to the central government for protection and relief. Fourth, the decentralization literature often assumes that different levels of government all have similar levels of technical and administrative capacity. However, the information and accounting systems and mechanisms of monitoring public officials in low-income and developing countries are quite weak and inadequate. In many developing countries the quality of staff in local bureaucracies (including basic tasks like accounting and record keeping) tends to be quite low, making it difficult to ensure the skills and capacities needed to promote macroeconomic growth as one of the benefits of fiscal decentralization.

There is also the issue of fixed costs associated with fiscal decentralization. For small, low-income and developing countries, high fixed costs could consume such a large share of a locality's total available funds that decentralization might seem difficult to justify. According to Fiva (2006:250-280), there is a relatively high threshold level of economic development at which fiscal decentralization becomes attractive. This level exists not only because of the fixed costs of fiscal decentralization, but also because at a relatively low per capita income level, the demands for public goods and services may be so homogeneous that the central government has all information necessary to provide for consumer and producer efficiency (Thiessen, 2003:237-274).

\subsubsection{Capture}

Capture refers to when regional governments are beholden to local elites after power has been transferred to sub-national governments. While a central argument for fiscal decentralization is that it increases local influence over the public sector, there is a possibility that fiscal decentralization simply transfers power from national government to local elites, and that increased access of local elites to public resources of local governments increases opportunities for corruption (Glewwe, 2002:1-12; Bardhan, 2002:675-704). With capture of the local government, there is a tendency to over-provide the service to local elites at the expense of the non-elite. According to Stegarescu (2005:301-333), the extent of such inefficient and inequitable cross-subsidization will depend on the degree of fiscal autonomy of the local government The degree of capture also depends on a number of factors, such as, the level of social and economic inequality within communities, tradition of political participation and voter awareness, fairness and regularity of elections, transparency in local decision-making processes, media attention and other factors (Thiessen, 2003:237-274; Desai et al., 2005:814-834). The aggregate effects of capture are wastes, inefficiency, and low economic growth. When the potential for capture of sub-national governments is intense, decentralization programs if possible should focus on strengthening the mechanisms of local accountability.

\subsubsection{Social Fragmentation}

Fiscal decentralization may cause social fragmentation, whereby local governments continually try to cater to the needs of groups with similar interests. Brennan and Buchanan (1980) developed the "fragmentation hypothesis" which states that the competitive impact of fiscal federalism depends on the number of possible alternative jurisdictions available to voters and firms, and the transaction costs that migrations induce. The more jurisdictions that exist, the less costly is emigration. Thus, the potential for fiscal exploitation varies inversely with the number of competing governmental units (Brennan and Buchanan 1980). The more the numbers of jurisdictions, the lower the scope for taxation. However, taxation does not disappear completely. Where voters have a competing group-based social conscience, the social fractionalization created by the various groups reduces political support for redistribution and thereby reduces the size of government. In a more fragmented society, with individuals sorting themselves into more diverse communities, the result is a smaller government sector. This creates inefficiencies because increasing returns to scale in the consumption of public goods cannot be fully exploited since government may want to satisfy each competing faction. This consequently results in low macroeconomic efficiency and growth (Brennan and Buchanan, 1980; Freinkman, 2010:117-168). 


\section{Related Studies}

In this section, we bring together both theoretical and empirical literature on the relationship between fiscal decentralization and economic growth. Both literatures present studies that support the conflicting views on fiscal decentralization and economic growth, with more of the theoretical studies leaning towards a more positive relationship between fiscal decentralization and economic growth.

\subsection{Theoretical Literature}

The theoretical literature examines the channels through which fiscal decentralization affects economic growth. Tiebout (1956) presents a model in which efficiency in public goods consumption is associated with competition among local jurisdictions, whereby individuals are differentiated according to their preferences for government provisions of goods and services. In this welfare maximization setup, the link between fiscal decentralization and economic growth is indirect through how individuals save. Since Tiebout's model accounts for agglomeration effects, this gives a basis for other theoretical models (e. g. Baldwin and Krugman, 2004:1-23; Ottaviano and Thisse, 2004:2564-2608; Baldwin and Martin, 2004:2671-2711) on how productive activities that are spatially allocated can have agglomeration effects. These effects are important for four main reasons: i) scale effects which can reduce transport costs; ii) immobility of regional resources having impact on productive facilities; iii) knowledge spillovers or externalities; and iv) regional policies as drivers of agglomeration due to natural resources, health, education and other policies. Regional policies can also generate economic growth through the influence of both physical and human capital accumulation in those regions with idiosyncratic features. Hence, productive factors can be attracted to the regions with appropriate policies. These factors create differences in regions, and result in fiscal competition pressures which can enhance the market system (Weingast, 1995:31-53).

Using endogenous growth models, Brueckner (1999:205-224, 2006:2107-2120) includes publicly-provided goods with uniform lump sum taxes in both centralized and decentralized systems. He uses two population groups differentiated by age, and assumes the working of Tiebout (1956). Accordingly, there is relative demand for public goods by the old and young population groups. The different levels of demand of public goods by the two age groups produce different growth rates in both the centralized and decentralized systems, making the results inconclusive. It is important to note that the model brings out the different preferences of the respective population groups, with their different assumptions producing different outcomes. Furthermore, the public goods are financed from uniform lump sum taxes which do not give unambiguous growth outcomes.

Baldwin and Krugman (2004:1-23), in their "core-periphery models" link agglomeration to fiscal competition. Their analysis suggests that agglomeration with factor mobility leads to more economic integration, but results in increasing tax rates on the remunerations of the factors that are mobile. Generalizing such model to the whole economy with growth-oriented view, Brakman et al. (2002) show that given agglomeration, peripheral areas need to develop appropriate policies to attract businesses. Theoretically, transfers from rich to poor regions would affect spatial allocation of resources. Yet peripheral regional growth may be enhanced if the regions carry out their own fiscal policies rather than depend on grants or transfers from the central government (Barro, 1990:S103-S125). This may pose the problem of choosing the appropriate tax rate in maximizing welfare since a high tax rate would be detrimental to investment in the given region. The production function specification of Davoodi and Zou (1998:244-257) gives a positive increase of the amount of public goods, but the model shows that some public goods can be decentralized while others can not be completely decentralized. The results of these types of models are based on reduced-forms of a complex process.

The following questions underlie these reduced-form models of economic growth in a multi- tier government: i) Even when a centralized government can provide different types and amount of public goods to different regions, how efficiently can this really be done? ii) There is the information question, where it is believed that the decentralized fiscal system has a greater information advantage than the centralized one. Under what conditions and in what context can this be true? With regards to the appropriate supply of public goods, Besley and Coate (2003:2611-2637) provide political economy arguments for decentralization. They argue that the centralized government has incentives to over-supply public goods, which negatively affect growth. Hence, decentralization can solve this problem. Furthermore, it is argued that a multi-tier regime tends to be more efficient, provides more specific public goods to the given regions, and can carry out structural changes, thereby generating high growth. When discussing scale economies, small jurisdiction can not capture these economies of scale, yet there are a number of other benefits generating from fiscal decentralization (Akai et al., 2007:339-362; Rodden, 2003:695-729).

Modeling time-inconsistency problem, Edwards (2005:629-648) shows how human capital can promote growth in a decentralized system, while a centralized regime is associated with low human capital, high taxes, and consequently 
low growth. The study shows that while a decentralized system may be faced with out-migration pressure, it may also experience high rate of investment, low taxes and consequently high growth. The study also discusses the externalities related to public goods, which, depending on the extent of the externalities, may go far beyond the jurisdiction producing the public goods.

In explaining the effects of decentralization on economic growth and welfare, Chu and Yang (2012:177-188) model endogenous growth that includes capital mobility, leviathan taxation and public goods spillovers. The model identifies three main parameters: "i) the degree to which politicians are rent seeking; ii) the degree of spillovers of public goods across jurisdictions; and iii) the degree of capital mobility" (p. 179). Within this framework, it is shown that fiscal decentralization is growth dominant over fiscal centralization. Finally, Jin et al. (2005:1719-1742) study the effects of fiscal decentralization in China from 1982 to 1992 . The study shows that fiscal decentralization provides incentives to the provinces for innovative practices, and allows them to develop mechanisms to fight corruption. The result is an increase in economic growth and economic activities in the provinces.

On the whole, there are many channels through which fiscal decentralization affects growth: heterogeneous channel, market-preserving channel, structural change channel, and innovation channel (Feld et al., 2009). These theoretical studies provide a basis to demonstrate that the effects of fiscal decentralization on economic growth may be positive depending on a number of institutional constraints.

\subsection{Empirical Literature}

We examine the empirical literature on the relationship between fiscal decentralization and economic growth, which addresses the issue from different angles other than explicitly testing the channels through which fiscal decentralization affect economic growth. The empirical literature focuses on cross-country and single-country studies. Nearly all the models apply the following formulation:

$$
Z_{j}=\beta Y_{j}+\alpha D_{j}+\varepsilon_{j}(j=1,2, \ldots \ldots ., M) \text {; where }
$$

$\mathrm{Z}$ stands for economic growth, $\mathrm{Y}$ is a vector of other variables or control variables, $\mathrm{D}$ measures fiscal decentralization, $\varepsilon$ is the error term, $\beta$ and $\alpha$ are the parameters, with $M$ being the number of observations. While different studies have used different models, what is of greater interest is the fiscal decentralization variable.

Based on this formulation, empirical evidence tends to give contradictory results, with more studies indicating a positive influence of fiscal decentralization on economic growth than those showing negative effects (Akai et al., 2007:339-362). Furthermore, studies on developed countries (Martinez-Vazquez and McNab, 2003:1597-1616) tend to give a more robust positive relationship than those on developing countries (Feld et al., 2009). Yet there are some very robust single-country studies that focus solely on developing countries. Feltenstein and Iwata (2005:481-501) applied an autoregression model with Chinese data. The dependent variable is the growth rate of the gross national product, and the main independent variable represents measures of decentralization, without explicitly stating fiscal decentralization. They find a positive relationship between different measures of decentralization and economic growth.

It is important to note that the major issue in the empirical literature is how fiscal decentralization is measured. Since there are various levels and forms of fiscal decentralization, different studies tend to define and measure fiscal decentralization in different ways, with varying results. This implies that there seems to be no standard measure of fiscal decentralization indicator. Moreover, there is also the issue of design, and the context within which fiscal decentralization takes place. In certain cases, this may depend on a number of factors (such as, type of political system, the constitutional provision if there is any, the degree of institutional development or setting, the size of the country in terms of physical size and population, the level of economic development, and so on).

In Table 1, we depict the relationship between fiscal decentralization and economic growth based on population size and institutional development. The vertical axis measures the size of the population, from very small population size to large population size, such as China, India, and USA. The horizontal axis depicts the level of development of institutions. This also may also be reflective of the level of "democratic maturity". Empirical studies suggest that countries with strong degree of institutional development tend to have a positive relationship between fiscal decentralization and economic growth. Countries with large population size and weak institutions seem to have no positive relationship between fiscal decentralization and economic growth. The results are mixed with countries having small and medium size populations. Furthermore, since the nature of fiscal decentralization is heterogeneous and idiosyncratic, it is difficult to have a standard measurement of the fiscal decentralization variable. Hence, the measurement of fiscal decentralization variable would have significant impact on the outcome.

$<$ Insert Table Here $>$ 


\section{Discussion}

As mentioned in earlier sections of this paper, the benefits of fiscal decentralization include improved governance and efficiency of the public sector (Thiessen, 2003:237-274; Payne and Ewing, 1996:258-274). While the virtues of fiscal decentralization have long been recognized, its relationship with economic growth remains ambiguous. For example, local fiscal decision-making allows public services to be tailored to local preferences and circumstances, and offers a number of choices of local outputs. Similarly, decentralization can promote democratic processes through more direct involvement of the citizenry in public decisions. Even though most authors argue that fiscal decentralization brings about efficiency gains in the provision of public goods and services, there is no empirical or theoretical consensus on its impact on the total size of government and economic growth. A critical argument supportive of decentralization's influence on economic growth is that it increases allocative efficiency since sub-national governments, which are closer and more responsive to the needs and preferences of local residents, are given discretion to govern their own affairs. Even with these virtues, fiscal decentralization causes shortcomings, which require central government intervention. A growing view in the literature is that decentralization may aggravate fiscal imbalances, thereby, endangering overall macroeconomic stability, unless sub-national governments are committed to fiscal discipline, and the decentralization package includes incentives for prudence in debt and expenditure management (Chen and Wu, 2008:119-135; Neck and Getzner, 2007:49-65).

The analysis suggests that regardless of the background and the motivation in different countries, it seems that the manner in which fiscal decentralization is carried out can have a significant impact on macroeconomic management and growth. The institutional context for decentralization (which includes the overall level of economic development, economic and political reforms, technical and administrative capacity of sub-national governments, geographic, demographic, and other factors) affect the impacts of fiscal decentralization on economic growth. Institutional reforms that minimize adverse incentives and promote transparency and accountability are key to an effective decentralized system, and possibly a positive impact on economic growth (Akai et al., 2007:339-362). On the other hand, the lack of strong institutional capacity, and firm and transparent rules that regulate intergovernmental relations, forcing sub-national governments to provide an adequate level of services while maintaining a sustainable decentralized system with fiscal discipline can result in adverse economic consequences. Healthy competition among local jurisdictions can encourage efficiency in the public sector and curb excessive growth in public budgets.

\section{Conclusion}

This paper examines the impacts of fiscal decentralization on economic growth. One of the arguments for fiscal decentralization is that it differentiates the provision of local outputs according to local tastes and circumstances, thereby increasing the effectiveness and efficiency of economic development. There are also the added benefits of accountability, revenue and political autonomy, and enhanced quality of public services. It seems that to be really effective fiscal decentralization has to focus on the institutional contexts of the society involved. Effective implementation of fiscal decentralization policies requires a comprehensive institutional framework. While the theoretical literature seems to be more supportive of a positive relationship between fiscal decentralization and economic growth, the empirical literature is somewhat inconclusive, but indicates the significance of the role of institutional development. Further investigation is needed to examine whether the institutional development should come first before the introduction of fiscal decentralization policies or vice versa.

\section{References}

Akai, N., Yukihiro, N., \& Masayo, S. (2007). Complementarity, Fiscal Decentralization and Economic Growth. Economics of Governance, 8(4). http://dx.doi.org/10.1007/s10101-007-0032-5

Alexeev, M., \& Habodaszova, L. (2012). Fiscal Decentralization, Corruption, and the Shadow Economy. Public Finance and Management, 12(1).

Baldwin, R., \& Krugman, P. (2004). Agglomeration, Integration and Tax Harmonization. European Economic Review, 48. http://dx.doi.org/10.1016/S0014-2921(02)00318-5

Baldwin, R., \& Martin, P. (2004). Agglomeration and Regional Growth. In J.V. Henderson \& J.F. Thisse (Eds.), Handbook of Regional and Urban Economics (Vol. 4). Elsevier, Amsterdam.

Barankay, I., \& Lockwood, B. (2007). Decentralization and the Productive Efficiency of Government: Theory and Evidence from Swiss Cantons. Journal of Public Economics, 91(5-6). http://dx.doi.org/10.1016/j.jpubeco.2006.11.006

Bardhan, P. (2002). Decentralization of Governance and Development. The Journal of Economic Perspectives, 16(4). http://dx.doi.org/10.1257/089533002320951037 
Bardhan, P., \& Mookherjee, D. (2005). Decentralizing Anti-Poverty Program in Delivery in Developing Countries. Journal of Public Economics, 89(4). http://dx.doi.org/10.1016/j.jpubeco.2003.01.001

Barro, R. (1990). Government Spending in a Simple Model of Endogenous Growth. Journal of Political Economy, 98. http://dx.doi.org/10.1086/261726

Besley, T., \& Coate, S. (2003). Centralized vs. Decentralized Provision of Local Public Goods: A Political Economy Approach. Journal of Public Economics, 87.

Bjedov, T., \& Madies, T. (2010). Corruption and Decentralization: What Economists Have to Say. Urban Public Economic Review, 13.

Brakman, S., Garretsen, H., \& Van Marrewijk, C. (2002). Locational Competition and Agglomeration: The Role of Government Spending. CESifo Working Paper No. 775, Munich, September 2002.

Brennen, G., \& Buchanan, J. (1980). The Power to Tax: Analytical Foundation of a Fiscal Constitution. New York: Cambridge University Press.

Brothaler, J., \& Getzner, M. (2010). Effects of Decentralization on Public Sector Growth in Austria. Public Finance and Management, 10(1).

Brueckner, J. (1999). Fiscal Federalism and Capital Accumulation. Journal of Public Economic Theory, 1. http://dx.doi.org/10.1111/1097-3923.00009

Brueckner, J. (2006). Fiscal Federalism and Economic Growth. Journal of Public Economics, 90. http://dx.doi.org/10.1016/j.jpubeco.2006.05.003

Chen, C., \& Wu, H. (2008). Fiscal Structures and Regional Economic Growth: Evidence from China. Journal of Developing Areas, 41(2). http://dx.doi.org/10.1353/jda.2008.0025

Chu, A., \& Yang, C. (2012). Fiscal Centralization versus Decentralization: Growth and Welfare Effects of Spillovers, Leviathan Taxation, and Capital Mobility. Journal of Urban Economics, 71. http://dx.doi.org/10.1016/j.jue.2011.10.003

Dabla-Norris, E. (2006). The Challenge of Fiscal Decentralization in Transition Countries. Comparative Economic Studies, 48(1). http://dx.doi.org/10.1057/palgrave.ces.8100063

Davoodi, H., \& Zou, H. (1998). Fiscal Decentralization and Economic Growth: A Cross Country Study. Journal of Urban Economics, 43. http://dx.doi.org/10.1006/juec.1997.2042

Desai, R., Freinkman, L., \& Goldberg, I. (2005). Fiscal Federalism in Rentier Regions: Evidence from Russia. Journal of Comparative Economics, 33(4). http://dx.doi.org/10.1016/j.jce.2005.08.004

Edwards, R. (2005). The Structure of Authority, Federalism, Commitment and Economic Growth. Economic Theory, 25. http://dx.doi.org/10.1007/s00199-003-0457-1

Feld, L., Baskaran, T., \& Schnellenbach, J. (2009). Fiscal Federalism, Decentralization and Economic Growth: A Meta-Analysis. Project report DFG-1142-German Science Foundation.

Feld, L., Kirchgassner, G., \& Schaltegger, C. (2010). Decentralized Taxation and the Size of Government: Evidence from Swiss State and Local Governments. Southern Economic Journal, 77(1). http://dx.doi.org/10.4284/sej.2010.77.1.27

Feltenstein A., \& Iwata, S. (2005). Decentralization and Economic Performance in China: Regional Autonomy has its Costs. Journal of Developing Economics, 76. http://dx.doi.org/10.1016/j.jdeveco.2004.01.004

Fiva, J. (2006). New Evidence on the Effect of Fiscal Decentralization on the Size and Composition of Government Spending. Finanzarchiv, 62(2). http://dx.doi.org/10.1628/001522106X120659

Freinkman, L. (2010). Fiscal Decentralization and the Quality of Public Services in Russian Regions. Public Finance and Management, 10(1).

Freinkman, L., \& Plekhanov, A. (2009). Fiscal Decentralization in Rentier Regions: Evidence from Russia. World Development, 37(2). http://dx.doi.org/10.1016/j.worlddev.2008.05.010

Glewwe, P. (2002). Schools and Skills in Developing Countries: Education Policies and Socioeconomic Outcomes. Journal of Economic Literature, 40(2). http://dx.doi.org/10.1257/002205102320161258

Golem, S. (2010). Fiscal Decentralization and the Size of government: A Review of the Empirical Literature. Finance Theory and Practice, 34(1).

Grewal, B. (2010). Symposium on Fiscal Decentralization. Public Finance and Management, 10(1). 
Jin, J., Qian, Y., \& Weingast, B. (2005). Regional Decentralization and Fiscal Incentives: Federalism, Chinese Style. Journal of Public Economics, 89. http://dx.doi.org/10.1016/j.jpubeco.2004.11.008

Kolluri, B., \& Panik, M. (2000). Government Expenditure and Economic Growth: Evidence from G7 Countries. Applied Economics, 32.

Kornai, J. (1979). Resource-Constrained versus Demand-Constrained Systems. Econometrica, 47.

Kornai, J. (1980). Economics of Shortage. Northland Publishing, Amsterdam.

Martinez-Vazquez, J., \& McNab, R. (2003). Fiscal Decentralization and Economic Growth. World Development, 31(9). http://dx.doi.org/10.1016/S0305-750X(03)00109-8

Miller, S., \& Russek, F. (1997). Fiscal Structures and Economic Growth at the State and Local Level. Public Finance Review, 25. http://dx.doi.org/10.1177/109114219702500204

Neck, R., \& Getzner, M. (2007). Austrian Government Expenditures: 'Wagner's Law' or 'Baumol's Cost Disease? International Business \& Economics Research Journal, 6(11).

Oates, W. (1977). An Economist's Perspective of Fiscal Decentralization. In W. E. Gates (Ed.), The Political Economy of Fiscal Federalism. Lexington Books, Toronto.

Oates, W. (1993). Fiscal Decentralization and Economic Development. Working Paper No. 93 94, University of Maryland.

Oates, W. (2005). Toward a Second Generation Theory of Fiscal Federalism. International Tax and Public Finance, 2. http://dx.doi.org/10.1007/s10797-005-1619-9

Ottaviano, G., \& Thisse, J. (2004). Agglomeration and Economic Geography. In J.V. Henderson and J. Thisse (Eds.), Handbook of Regional and Urban Economics (Volume IV). North-Holland, Amsterdam.

Payne, J., \& Ewing, B. (1996). International Evidence on Wagner's Hypothesis: A Cointegration Analysis. Public Finance, 51.

Rodden, J. (2003). Reviving Leviathan: Fiscal federalism and the Growth of Government. International Organization, 57(4). http://dx.doi.org/10.1017/S0020818303574021

Shah, A., \& Shah, F. (2007). Strategies to Combat Democratic Deficits. Development, 50(1). http://dx.doi.org/10.1057/palgrave.development.1100327

Stegarescu, D. (2005). Public Sector Decentralization: Measurement Concepts and Recent International Trends. Fiscal Studies, 26. http://dx.doi.org/10.1111/j.1475-5890.2005.00014.x

Thiessen, U. (2003). Fiscal Decentralization and Economic Growth in High-Income OECD Countries. Fiscal Studies, 24(3).

Tiebout, C. (1956). A Pure Theory of Local Expenditure. Journal of Political Economy, 64(5). http://dx.doi.org/10.1086/257839

Vazquez, J., \& McNab, R. (2003). Fiscal Decentralization and Economic Growth. World Development, 31.

Vigneault, M. (2010). Fiscal Decentralization with Regional Redistribution and Risk Sharing. Public Finance and Management, 10(1).

Weingast, B. (1995). The Economic Role of Political Institutions: Market-Preserving Federalism and Economic Development. Journal of Law, Economics and Organization, 11(1).

Table 1. Effects of fiscal decentralization on economic growth

\begin{tabular}{|c|c|c|c|}
\hline \multirow{4}{*}{ Size of Population } & & \multicolumn{2}{|c|}{ Strong Weak } \\
\hline & Large & + growth & Possible no growth \\
\hline & Medium & + growth & Not clear \\
\hline & Small & + growth & Not clear \\
\hline
\end{tabular}

Degree of Institutional Development

Source: Authors' Table. 